\title{
Mesleki Özdeşleşme ve Psikolojik Sahiplenme Çalışanların İş Biçimlendirmelerine Etki Eder Mi?: Hizmet Sektörü Çalışanlarına Yönelik Bir Araştırma (Do Occupational Identification and Psychological Ownership Affect The Employees' Job Crafting?: A Research on Service Sector Employees)
}

\author{
Memduh BEGENİRBAŞ iD a Yunus GÖKMEN iD b Rukiye CAN YALÇIN iD c \\ a MSÜ Kara Harp Okulu, Savunma Araştırmaları Bölümü, Ankara, Türkiye. mbegenirbas@kho.edu.tr, \\ b MSÜ Kara Harp Okulu, Endüstri Mühendisliği Bölümü, Ankara, Türkiye. yunusgokmen@gmail.com, \\ b MSÜ Kara Harp Okulu, Savunma Araştırmaları Bölümü, Ankara, Türkiye. rcyalcin@kho.edu.tr,
}

\begin{tabular}{|c|c|}
\hline MAKALE BİLGİSİ & ÖZET \\
\hline $\begin{array}{l}\text { Anahtar Kelimeler: } \\
\text { Mesleki özdeşleşme }\end{array}$ & $\begin{array}{l}\text { Amaç - Bu çalışmanın amacı mesleki özdeşleşme ve psikolojik sahiplenme düzeyinin çalışanların iş } \\
\text { biçimlendirme davranışlarındaki etkisini ortaya koymaktır. }\end{array}$ \\
\hline $\begin{array}{l}\text { Psikolojik sahiplenme } \\
\text { İş biçimlendirme }\end{array}$ & $\begin{array}{l}\text { Yöntem - Araştırmamızın evreni Türkiye'deki hizmet sektörü çalışanları, örneklemini ise Ankara' da görev } \\
\text { yapan güvenlik, eğitim, sağlık, finans gibi hizmet alanlarında çalışanlar oluşturmaktadır. Bu bağlamda, } \\
\text { Ankara'da görev yapan hizmet sektörü çalı̧̧anlarından elden ve elektronik ortamda doldurulan anket }\end{array}$ \\
\hline $\begin{array}{l}\text { Gönderilme Tarihi } 3 \text { Mart } \\
2021\end{array}$ & $\begin{array}{l}\text { formlarından } 442 \text { katılımcıya ait veriler analiz edilmiştir. Çalışmada değişkenler arası ilişkiler ve etkilerini } \\
\text { belirlemek için korelâsyon ve regresyon analizleri gerçekleştirilmiş, değişkenlere ait ölçeklerin } \\
\text { doğrulanması için ise yapısal eşitlik modeli kullanılmıştır. }\end{array}$ \\
\hline $\begin{array}{l}\text { Revizyon Tarihi } 16 \text { Mayıs } \\
2021\end{array}$ & $\begin{array}{l}\text { Bulgular - Hizmet sektörü çalışanlarını mesleki özdeşleşme düzeyinin iş biçimlendirme davranışlarını } \\
\text { anlamlı ve pozitif sekilde etkilediği görülmüstür. Benzer sekilde yine işlerini psikoloijk olarak sahiplenen }\end{array}$ \\
\hline \multirow{2}{*}{$\begin{array}{l}\text { Kabul Tarihi } 5 \text { Haziran } \\
2021\end{array}$} & çalışanların daha çok iş biçimlendirme davranışları sergiledikleri sonucuna varılmıştır. \\
\hline & $\begin{array}{l}\text { Tartışma - Bu çalışma mesleki özdeşleşme ve psikolojik sahiplenme düzeylerinin iş biçimlendirme } \\
\text { davranışlarına etkisini ortaya koymaya çalışmaktadır. Yazında hizmet sektörü çalışanları açısından söz }\end{array}$ \\
\hline Makale Kategorisi: & konusu değişkenlerin ikili ilişkilerini ele alan çalışmaların oldukça sınırlı sayıda olduğu görülmüş, üç \\
\hline Araştırma Makalesi & $\begin{array}{l}\text { değişkeni birlikte inceleyen bir çalışmaya ise rastlanamamıştır. Bu bağlamda çalışma sonuçlarının hem } \\
\text { yazın hem de uygulayıcılar açısından olduğu değerlendirilmektedir. }\end{array}$ \\
\hline
\end{tabular}

\section{ARTICLE INFO}

\section{Keywords:}

Occupational

identification

Psychological ownership

Job crafting

Received 3 March 2021

Revised 16 May 2021

Accepted 5 June 2021

Article Classification:

Research Article

\section{ABSTRACT}

Purpose - The aim of this study is to reveal the effect of occupational identification and psychological ownership level on employees' job crafting behaviors.

Design/methodology/approach - The population of our research consists of service sector employees in Turkey, and the sample consists of those working in service areas such as security, education, health and finance in Ankara. The data of 442 participants from the questionnaire forms filled in hand and electronically from service sector employees working in Ankara were analyzed. In the study, correlation and regression analyzes were performed to determine the relationships and effects between variables, and the structural equation model was used to verify the scales of the variables.

Findings - When the findings are examined, it was seen that the level of professional identification of service sector employees significantly and positively affects job crafting behaviors. Similarly, it was concluded that employees psychologically adopting their jobs exhibit more job crafting behaviors.

Discussion - This study tries to reveal the effect of occupational identification and psychological ownership levels on job crafting behaviors. Quite a limited number of studies dealing with the bilateral relations of these variables in terms of service sector employees have been observed in the literature, and no study examining the three variables together has been found. In this repect, the findings of this study is thought to be importatant both for the literature and the practitioners. 


\section{Giriş}

Günümüzdeki bilgi ve teknolojideki hızlı gelişim örgütlerin esnek yapılanması ve değişimlere çabuk reaksiyon vermesi gerekliliğini beraberinde getirmektedir. Bilgi çağı olarak da adlandırılan, örgütler açısından esneklik gerektiren söz konusu yeni ekonomik sistemin gerekleri (Fayganoğlu, 2019), örgüt ve iş tasarımlarında da çalışanların görevlerini etkili olarak şekillendirme ve biçimlendirmelerini zorunlu kılmaktadır. Ayrıca, örgütler daha iyi iş sonuçları elde etmek, üretken olmayan davranışlardan ve yüksek iş gücü değişiminden kaçınmak isterken, yetenekli ve kalifiye personeli de bünyelerinde tutmak istemektedirler. Bu nedenle, yetenekli çalışanların meslekleri ve örgütleriyle özdeşleşmeleri, örgütlerine sahiplik duygusuyla bağlanmaları örgütlere daha yüksek düzeyde entelektüel sermaye sağlarken aynı zamanda örgütler, çalışanlarının kendi işlerini örgüt performansına olumlu katkılar sağlayacak şekilde tasarlamalarına ihtiyaç duymaktadır.

Mesleki özdeşleşme, çalışanların yaşamlarında henüz örgütsel ortamlara girmeden, mesleki eğitim hatta belki çocukluk dönemlerine kadar uzanan bir dönemde gelişmeye başladığı için pek çok davranış ve tutumun açıklanmasında güçlü bir belirleyici özellik taşımakta, çalışanın kendini ifade etme şekline dönüşmektedir (Doğan, 2020:26). Bu kapsamda mesleki özdeşleşme kavramı, çalışanların örgütsel tutum ve davranış sonuçlarını etkilemesi, açıklanması ve yol gösterici özellikler taşıması bakımından önemlidir. Bir başka önemli örgütsel davranış kavramı olan psikolojik sahiplenme çalışanların yaptıkları işleri anlamlı kılması ve başarılı bir şekilde yapmalarına etki etmektedir (Vandewalle vd., 1995). Psikolojik sahiplenme insana özgü, doğuştan gelen önemli bir duygu olarak sahipliğin bazı temel ihtiyaçlarının karşılanması ile belirip davranışsal sonuçlara yol açabilmektedir (Pierce vd., 2001). Bu kapsamda psikolojik sahipliğin altındaki motivler ve çalışanları bu motivlere götüren temel yolları bilmemiz, örgütlerdeki insan gücünü daha iyi anlamak, istek ve beklentilerine daha hızlı cevap verebilmek ve kalifiye çalışanı örgütlerde tutabilmek açısından önemlidir (Olckers ve Plessis, 2012).

Mesleki özdeşleşme ve psikolojik sahiplenmenin, çalışanların yaptıkları işlere, görevlerini yapmaları için kurdukları her türlü sosyal ilişkilere ve işleri hakkındaki bilinç ve algı düzeylerine etki edebileceği gerçeğinden hareketle bu çalışmanın yapılması düşünülmüştür. Alan yazın incelemesinde çalışanların mesleki özdeşleşme algıları ile yaptıkları işleri psikolojik olarak sahiplenmelerinin onların iş biçimlendirmelerine olan etkilerini birlikte ve tek bir model üzerinde ele alan gerek uluslararası gerekse ulusal yazında herhangi bir çalışmaya rastlanılmamış olması bu çalışmanın yapılmasını önemli kılmaktadır. Ayrıca alan yazına katkıları yanında bu çalışmanın kurum, kuruluş, işletme ile yönetici ve çalışanlar açısından yönetim fonksiyonlarının uygulanması ile tutum ve davranışlara önemli girdiler sağlayabileceği değerlendirilmektedir.

Çalışmanın amacı değişik hizmet sektörlerindeki (eğitim, sağlık, finans, güvenlik vb.) hizmet çalışanlarının mesleki özdeşleşme ve psikolojik sahiplenme algılarının onların iş biçimlendirme tutum ve davranışlarına olan etkilerini bütüncül bir model içerisinde ortaya koymaktır. Bununla birlikte, çalışmanın sonuç bölümünde elde edilen bulgular doğrultusunda, hizmet sektörü kurum ve kuruluşlarının yönetici ve insan kaynakları bölümleri ile benzer çalışmalar yapacak araştırmacılara önerilerde bulunulmuştur.

\section{Kavramsal Çerçeve ve Hipotezler}

\section{1. İş Biçimlendirme}

Bir örgütün yönetiminde kullanılan en değerli kaynak beşeri sermaye ve söz konusu insan gücünün örgütün başarısı ve performansına katkısı doğrudandır. Çalışanların ise olumlu katkıları örgütlerindeki memnuniyet düzeyleri, işlerini değerli ve anlamlı görmeleri, yaptıkları işleri içselleştirerek sahiplenmeleri ve kendileri ile özdeştirmeleri ile mümkündür (Gillet vd., 2013). Ayrıca çalışanların yaptıkları işleri ve görevlerini yerine getirirken diğer çalışanlar ile ilişkilerini anlamlı bulmaları ve zihinlerinde belli bir yere konumlandırmaları işin başarılması ve çalışan performansı açısından önemlidir (Qing vd., 2019). İşte bu noktada örgütsel davranış alanında yeni bir kavram olan iş biçimlendirme üzerinde durulması gerekmektedir.

İş biçimlendirme, yeni bir kavram olarak ilk defa Wrzesniewski ve Dutton (2001) tarafından alan yazındaki bir çalışmada kullanılmasına karşın aslında daha önce yapılan çalışmalarda ortaya çıkarılan rol yenilikçiliği (Katz ve Kahn, 1966), şekil verme (Bell ve Staw,1989), görev revizyonu (Staw ve Boettger, 1990) gibi 


\section{Begenirbaş - Y. Gökmen - R. Can Yalçın 13/2 (2021) 1127-1143}

kavramlardan esinlenmiştir (Yavuz, 2018). İngilizcesi "Job Crafting" olan kavram Türkiye'de yapılan çalışmalarda iş zanaatkarlı̆̆l, iş şekillendirme, iş becerikliliği ve iş biçimlendirme (Akın vd. 2014) şeklinde değişik çalışmalarda kullanılmıştır. Bu çalışmada ise kavram, Türkiye'de son dönemde gerçekleştirilen Örgütsel Davranış Kongrelerinde daha çok kabul gören şekli ile iş biçimlendirme olarak ele alınacaktır.

Wrzesniewski ve Dutton (2001) iş biçimlendirme kavramını, çalışanın görevine yönelik olarak icra ettiği faaliyetler ile çalışma ortamındaki kişilerle olan ilişkilerine uygulamak üzere yapmış olduğu her türlü fiziksel ve bilişsel tasarım ile değişimler olarak nitelendirmişlerdir. Söz konusu bu değişiklikler çalışanların yaptıkları işlere uyumlarını sağlarken yapılan görevlerin ister ve özelliklerinin de çalışanlar tarafından şekillendirilmesi, tasarlanması ve görevin özelliklerine uygun gerekliliklerin oluşturulmasını da mümkün hale getirmektedir (Kirkendall 2013).

Örgütsel davranış yazınında kullanılan biçimlendirme (crafting) kelimesi geleneksel biçimde üst yöneticiler tarafından ortaya konan iş tasarımından farklı olarak, çalışanların kendi görev ve sorumlulukları ile yaptıkları işlere anlam yüklemelerini, gerekli ilişkileri kurmalarını ve bu süreci bilişsel olarak değiştirebilme yetisine sahip olarak ustalıkla işletebilmelerini beraberinde getirmektedir. Hatta iş biçimlendirme davranışının, post modern örgütlerde geleneksel iş tasarımına göre daha sürdürülebilir ve verimli iş çıktıları yaratabileceği ve çalışanların yeteneklerini artırabileceği öngörülmektedir (Kira vd., 2010). Bir anlamda iş biçimlendirmede, çalışanların yaptıkları işlerin bizzat kendileri tarafından tasarlanması fikri öne çıkmakta ayrıca bireysel performans ve görevin anlamlı olması arzusu örgüt performansından daha öncelikli hale gelmektedir (Wrzesniewski ve Dutton, 2001). İş biçimlendirmede iş tasarımında olduğu gibi yönetim kademesi olarak yukarıdan aşağıya doğru bir biçimlendirme söz konusu değildir. Aksine çalışanın kendi yetenek ve düşüncelerini işine yansıtması, görevi ile ilgili gerekli etkileşim ve bilişsel yapıyı kendisinin kurgulaması söz konusudur.

Tims arkadaşları (2012) tarafından İş Gerekleri-Kaynakları Modeli temelinde geliştirilen iş biçimlendirme; yapısal iş kaynaklarını artırmak, sosyal iş kaynaklarını artırmak, zorlu iş taleplerini artırmak ve iş taleplerini azaltmak olarak dört boyutta değerlendirilirmiştir. Diğer yandan, Wrzesniewski ve Dutton (2001) ile Slemp ve Vella-Brodrick (2013) ise iş biçimlendirmeyi; görev, bilişsel ve ilişkisel biçimlendirme olarak üç alt boyutta ele almışlardır. Ayrıca iş biçimlendirme farklı çalışmalarda (Leana vd.,2009; Berg vd.,2010; Petrou vd., 2015; Lichtenthaler ve Fischbach, 2016) değişik sayıda alt boyut ve isimlerle alan yazında çalışılmıştır. Genel anlamda alan yazında iş biçimlendirmenin üç boyutlu hali daha çok kabul görmüş olması nedeniyle bu çalışmada da iş biçimlendirme Görev biçimlendirme, İlişkisel biçimlendirme ve Bilişsel biçimlendirme alt boyutları ile ele alınmıştır.

Görev biçimlendirme, çalışanın kişisel yetenekleri ve becerileri ile iş hayatında harcadığı emeğin miktarını veya zamanını ayarlamak ve tasarlamaktır (Kerse, 2017). Görev biçimlendirme sayesinde çalışanlar, işlerinde daha az veya daha fazla görev alarak, üstlendikleri görevlerin kapsamını ve görevi başarıyla gerçekleştirmek için kullanılan araçları değiştirerek görevlerini aktif olarak şekillendirmektedirler (Niessen, 2016). İlişkisel biçimlendirme, iş yeri odaklı ilişkilerin sayısı, kalitesi ve ölçüsünün ayarlanması noktasında çalışanın görevini icra ederken kimlerle ve hangi seviyelerde etkileşim ve iletişim içerisinde olduğunu ifade etmektedir (Wrzesniewski ve Dutton, 2001, Niessen vd., 2016). Bir anlamda ilişkisel biçimlendirme, çalışanın görevini yaparken etkileşimde bulunduğu tüm paydaşlara yönelik gösterilen davranışlarıdır (Ghitulescu, 2007). Görev ve ilişkisel biçimlendirmeden farklı olarak, bilişsel biçimlendirmede elle tutulur ve gözle görülür bir yapılanma veya değişiklik söz konusu değildir (Slemp ve Vella-Brodrick, 2013). Bilişsel biçimlendirme, çalışanların işlerine ilişkin algılarının yeniden düzenlenmesi ve işin bilişsel temsilinin değiştirilerek çalışanın yapacağı işi ve işle ilgili gireceği etkileşimleri zihinsel olarak ve bütüncül bir yaklaşımla algılama şekli ve eylemidir (Berg vd., 2013). İş biçimlendirme sayesinde çalışanlar değer verdikleri işlerine değişik anlamlar yükleyerek yapılması gerekenlere ilişkin görev, ilişki ve bilişsel anlamda yeni bir çerçeve çizme imkânına kavuşurlar. Bu sayede çalışanlar sahip oldukları bilgileri ve yetenekleri işlerine aktarabilme fırsatı bulabilirler.

\subsection{Mesleki Özdeşleşme}

Sosyal kimlik araştırmalarında, genellikle örgütsel kimliği keşfetmeye yönelik çalışmalara sıklıkla rastlanılmasına karşın son zamanlarda mesleki kimlik veya profesyonel kimlik üzerine yapılan araştırmalar yaygın hale gelmeye başlamıştır (Miscenko ve Day, 2016). Çalışma ve mesleki statü, insanların yaşamlarında çok önemli bir rol oynadığı için, kişinin mesleğinin önemli bir kimlik belirleme hedefi olduğunu varsayabiliriz (Kreiner ve Ashforth, 2004). Mesleki kimlik, bir çalışanın kendisinin ve yaptığı işin bilinçli farkındalığını ifade 


\section{Begenirbaş - Y. Gökmen - R. Can Yalçın 13/2 (2021) 1127-1143}

eder. Ayrıca mesleki kimlik, çalışanların kendilerini mesleki veya mesleki rollerinde tanımladıkları nitelikler, inançlar, değerler, güdüler ve deneyimlerden oluşan nispeten istikrarlı ve kalıcı özellikler olarak tanımlanmıştır (Ibarra, 1999). Modern toplumlarda mesleki kimlik oluşum süreci zor ve stresli olabilir. Bununla birlikte güçlü, isteyerek seçilmiş, pozitif ve esnek bir mesleki kimliğin oluşturulması mesleki başarıya, sosyal uyuma ve psikolojik iyiliğe önemli bir katkı olarak görülmektedir (Skorikov ve Vondracek, 2011). Bu kapsamda çalışanın mesleki kimliği ile kişisel kimliği birbirleriyle iç içe olarak benzeştikçe ya da çalışan kendi kimliğini mesleki kimliğinden ayrı tutamayacak zihinsel bir oluşuma sahip olma noktasına geldiğinde mesleki düzeyde bir özdeşleşmenin varlığından söz edilebilir (Kırkbeşoğlu ve Tüzün, 2009).

Mesleki özdeşleme aslında "Sosyal Kimlik" ve "Benlik Sınıflandırma" kuramlarına dayandırılabilir. Sosyal kimlik teorisi; kişilerin kendilerini ve diğer kişileri örgütsel üyelik, meslek, dini bağlllık, cinsiyet, yaş ve medeni durum gibi sosyal sınıflar altında kategorize eder (Tajfel ve Turner, 1985). Kişiler dâhil oldukları sınıfın bir üyesi olarak kendilerini süreç içerisinde algılayarak söz konusu sınıf veya grubu kendileri ile özdeşleştirirler. Benlik sınıflandırma kuramının ortaya attığı şekilde de kişiler kendilerini sınıf ve grup içerisinde bireysel düzeyde ayırıma tabi tutabilirler (Van Dick vd, 2005). Kısaca kişinin ait olduğu örgüt/grup kimliği ve sonrasında da kişisel benlik kimliği belli bir süreç içerisinde birbirine ilintili olarak oluşmaktadır. Mesleki özdeşleşme, kişinin kendisini yaptığı iş ve bu işi yapan kişilere atfedilen prototip özellikler açısından ne ölçüde benzeştirdiği ve tanımladığı anlamına gelmektedir (Mael ve Ashforth, 1992). Mesleki özdeşleşme, çalışanın kariyerine anlam ve yön veren, stres ve zorluklar ile başa çıkabilme yeteneklerini arttıran ve bireyin kişisel güçlerini, ilgilerini, tercihlerini ve amaçlarını mesleğinde bulmasını sağlayan bir özellik taşımaktadır (Hirschi, 2012). Bir kişinin yaşamı boyunca, mesleki eğitim, öğretim ve sosyalleşmenin bir sonucu olarak, örgütsel özdeşleşmeden önce mesleki kimliğin gelişmesi beklenebilir (Bamber ve Iyer, 2002). Çalışanlar bir organizasyondan ayrılsalar bile, genellikle mesleki bağlarını korurlar. Bu nedenle, mesleki özdeşleşmenin herhangi bir örgüte bağlı olmadan da geçerli olabileceğini söylemek mümkündür. Mesleki özdeşleşmede, bilişsel olarak çalışanın kendini yaptığı iş ile özdeşleştirerek işin gerekliliklerini hissetmesi, mesleğin değerlerini tamamıla kabul ederek içselleştirmesi ayrıca duygusal olarak yaptığı işten gurur duyması söz konusudur (Riketta, 2005). Çalışanların kendilerini meslekleri ile özdeşleştirmeleri, o mesleğin değerleri ve bakış açısından etrafa bakmalarını sağlarken, yaşananları düşünme, değerlendirme ve uygulamaya sokmalarını da bir o kadar meslekleri ile bağlantılı hale getirir (Ashforth ve Mael, 1989).

\subsection{Psikolojik Sahiplenme}

Örgütler, üretkenlikleri ve performanslarını artırmak, istenen belirli çalışan davranışlarını teşvik etmek anlaminda son zamanlarda alan yazında duyulmaya başlanan "Psikolojik Sahiplenme"yi önemli bir araç olarak kullanabilmektedirler. Özellikle örgütlere yönelik sahiplik düşüncesi (maddi veya maddi olmayan nesnelere yönelik "benim" veya "bizim" düşüncesi) çalışanların tutum ve davranışlarının potansiyel bir yordayıcısı olarak düşünülmektedir (Pierce vd., 1991; Brown vd., 2014). Daha önceki çalışmalarda (Florkowsky, 1987; Buchko 1992), çalışanların örgütlerine finansal olarak ortak olmalarının (yasal sahiplik) onların moral, motivasyon ile performansları üzerinde olumlu etkiler yapacağ 1 fikri üzerinde durmuştur (Vandewalle vd., 1996). Ancak araştırma bulguları, çalışanların olumlu tutum, davranış ve performanslarına yönelik bazı çelişkili sonuçlar vererek durumun her zaman böyle olmayabileceğini ortaya koymuştur (Pierce ve Furo, 1991). Çalışanların bir şeye yasal olarak sahip olmaları (fiziksel hak, kullanma hakkı, bilgi alma hakkı) üzerinden psikolojik sahiplenme kavramını ortaya koyan Pierce ve arkadaşları (1991), yasal sahiplik durumu olmadan da çalışanların görevlerine ve örgütlerine ilişkin sahiplenme duygusu geliştirebileceklerini söylemişler ve bu durumu psikolojik sahiplenme kavramı ile açıklamaya çalışmışlardır. Psikolojik sahiplenme kavramı bilişsel ve duygusal olarak deneyimlenebilen çok boyutlu bir kavramdır (Pierce vd., 1991; Maritz, 2011).

Örgütsel yazında psikolojik sahiplenme sadece belirli bir hedef veya nesneler üzerindeki fiziksel sahiplenmeyi değil, aynı zamanda bir kavram, bir iş veya tüm organizasyon üzerindeki sahiplenme duygu ve algısını ifade etmektedir. Psikolojik sahiplenme, "Neyin benim olduğunu hissediyorum?" sorusuna verilen yanıt olarak görülmekte ve yasal sahiplikten farklı olarak bir nesneyi sanki kendininmiş gibi kabul etme ve hissetmesidir (Pierce ve Jussila, 2011). Psikolojik sahiplenme, kişilerin kendilerine yakın hissettikleri ve benliklerinin bir parçası haline gelen nesneler (sahiplik hedefleri) arasındaki ilişkileri yansıtmaktadır (Bora, 2019). Psikolojik sahiplenme, başlangıçta organizasyon ve yönetim yazını dışında tanımlanmasına karşın, zaman içinde Pierce 


\section{Begenirbaş - Y. Gökmen - R. Can Yalçın 13/2 (2021) 1127-1143}

ve arkadaşları (2009) tarafından çalışma ortamına uygulanan bir olgu olarak ele alınmıştır. Psikolojik sahiplenmenin özünü, sahiplenme duygusu ve psikolojik olarak bir nesneye bağlı olma durumu oluşturmaktadır. Kişinin kendini sahipliğin odağında ya da sahipliğin bir parçasıymış gibi hissetmesinin bir ifadesi olan psikolojik sahiplenme, belirli koşullar altında çalışanların örgütlerine yönelik geliştirdikleri sahiplik duygusu olarak tanımlanmaktadır (Pierce vd., 2001). Mahhew ve arkadaşları ise (2007) psikolojik sahiplenmeyi, yasal kullanım hakkının yokluğundaki sahiplenme duygusu olarak görmektedir. Psikolojik sahiplenmede kişi kendini hedefin sahibi veya hedefin bir parçasının sahibi gibi hissetmesi durumu söz konusudur (Bora, 2019).

Pierce ve arkadaşlarının çalışmalarında (2001, 2003) ifade edildiği şekliyle psikolojik sahiplenme teorisi, kişisel sahiplenme duygularının doğuşunun büyük olasılıkla sosyo-biyolojik olduğunu savunur. Dittmar (1992) tarafından önerildiği gibi, sahiplenme duygusu, kişinin maruz kaldığı sosyalleşme uygulamaları ile pekiştirilen, toplama ve sahip olma eğiliminin doğuştan gelen bir birleşimi olabilir. Kişiye ait dört güdü, sahiplik duygusunun temelini ve köklerini oluşturur. Bunlar; etki motivasyonu (effectance motivation), öz kimlik (self-identity), ait olma/yuva (home) ve dürtü (stimulation)'dür. Bu güdüler, psikolojik sahiplenme durumunun varlığının nedeni olarak görülmektedir. Bir kişi belirli bir hedef için sahiplenme duygusu yaşadığında, bu güdülerin bir veya daha fazlasının karşılandığına inanılır.

Psikolojik sahiplenme durumu karmaşıktır. İnsanların temas kurdukları her hedef için bir sahiplenme duygusu beslemedikleri açıktır. Doğada hem maddi (örneğin, araba, telefon vb.) hem de maddi olmayan (örneğin fikirler, düşünceler vb.) nesneler için sahiplenme duygusu gelişebilmektedir. Sahiplenme duygusunun temelini oluşturan güdülere cevap verebilecek hedef niteliklerin psikolojik sahibin dikkatini çekmek ve tutmak için hem görünür hem de çekici ayrıca kişinin entelektüel algı yoluyla farkına varma durumunda olması beklenmektedir. Psikolojik sahiplenme, bir bireyin sahiplik hedefi ile ilgili farkındalığını, düşüncelerini ve inançlarını yansıtır. Bununla birlikte, bu bilişsel durum, duygusal veya bir his ile birleştirilir. Sahiplenme duygularının etkinlik ve yeterlilik duygusu eşliğinde, kişide bir istek ve mutluluğa neden olduğu söylenir. Psikolojik sahiplenme durumu, örgütsel davranış yazınında bazıları olumlu (örneğin; iş tatmini, örgütsel bağlllık, örgütsel değişimin teşviki, sorumluluk üstlenme, örgütsel vatandaşlık davranışı, koruyucu bölgesel davranışlar) kişisel ve örgütsel etkiyle ilişkilendirilebilirken, diğer etkiler doğası gereği olumsuz olabilmektedir (örneğin; örgütsel değişime/paylaşıma direnç, bilgi saklama/biriktirme, stres ve sorumluluk yükü, sapkın davranışlar) (Olckers ve Plessis, 2012; Pierce ve Peck, 2018). Bu kapsamda, psikolojik sahiplenmenin "teşvik edici" ve "önleyici" yönleri bulunmakta (Pierce vd., 2001; Avey vd., 2009) ve örgütlerin üretkenlikleri ile performansları üzerinde gerçekten önemli etkileri olduğu değerlendirilmektedir.

\subsection{Mesleki Özdeşleşme, Psikolojik Sahiplenme ve İş Biçimlendirme Arasındaki Kavramsal İlişkiler}

Araştırmalar mesleki özdeşleşmenin, ekstra rol davranışları, örgütsel vatandaşlık davranışları, iş performansı, iş tasarımı ve daha genel olarak örgütsel bağlllık gibi özellikle büyük organizasyonel değişim süreçlerinde önemli örgütsel sonuçları beraberinde getirdiğini göstermiştir (Witt, 1993; Snape ve Redman, 2003; Van Dick vd., 2004; Ashforth vd., 2013). Bu bulguları temel alarak, mesleği ile özdeşleşen çalışanların, görev tanımlarında bulunan, hatta görevleri olmasa dahi örgütlerinin iyiliği için yaptıkları işlere yönelik iyileştirme ve biçimlendirme yaparak kendi ve örgütlerinin performans ve üretkenliklerine olumlu katkıda bulunabilecekleri düşünülebilir.

Loi ve arkadaşları (2004) mesleki kimliğin ve özdeşleşmenin çalışanların iş tatmini, örgütsel bağlılık, iş biçimlendirme gibi iş tutumlarını açıklamada anahtar bir yapı olduğunu belirtmişlerdir. Bu bağlamda örgütsel ve bireysel performans ile üretkenlik açısından örgüt çalışanlarının algıları önemli bir rol oynadığından mesleki özdeşleşmenin de çalışanların işlerini biçimlendirmeleri, onların tecrübe ve sosyal ilişkilerini örgüt yararına kullanmaları beklenen bir sonuç olarak karşımıza çıkmaktadır. Ayrıca mesleki özdeşleşmenin, çalışanların görevlerini yaparken işbirliği yapma ve çevresindekilerle kaliteli ilişki ve etkileşim içerisinde bulunma istekliliği üzerinde önemli olumlu etkisi olduğu belirtilmektedir (Kroon ve Noorderhaven, 2018). Son araştırmalardan elde edilen ampirik bulgular, artan örgütsel ve mesleki özdeşleşme algısına sahip çalışanların buna karşı olumlu tutumlar geliştirdiklerini, faydalı örgütsel ve kişisel davranışlar gösterme konusunda daha motive olduklarını ve iş biçimlendirme çabalarının organizasyon ve meslekleri için değerli olduğuna inandıklarını ortaya koymuştur (Hur vd., 2017 ; Wang vd., 2017a ). 
Psikolojik sahiplenmenin çalışanların örgüt açısından olumlu ekstra rol davranışları göstermelerine neden olduğunu ve ayrıca çalışanların hissettikleri sahiplik inançları ile örgütlerin finansal performansları ve çalışanların işlerine karşı tutum ve davranışları arasında olumlu ilişkilerin olduğunu gösteren çalışmalar mevcuttur (Vandewalle vd., 1995; Wagner, vd., 2003; Van Dyne ve Pierce, 2004; Luthans vd., 2007).

Hackman ve Oldham (1975), İş Karakteristik Teorisinde üç kritik psikolojik durum olan, işin anlamlılı̆̆ını deneyimleme, iş sonuçları için deneyimli sorumluluk ve sonuçların bilgisini elde etmenin iş tasarımını etkileyen durumlar olduğunu belirtmiştir. Bu kapsamda psikolojik sahiplenmenin de iş tasarımı ve biçimlendirmesi üzerinde etkileri olabileceği değerlendirmesi yapılabilir (Pierce ve Peck, 2018).

Psikolojik sahiplenme neticesinde yaptığı görevi ve sorumluluğundaki malı ve mülkü bakıcısı (bekçikoruyucu) gibi hisseden çalışanlar, görevi ve sorumluluğundaki malı ve mülkü için düşünmeye, idare etmeye, riskler almaya ve kişisel fedakârlıklar yapmaya yönelerek söz konusu alanlarda belirli tasarım, şekillendirme ve uygulamalara gitmektedirler. Bu kapsamda çalışanların artık içselleştirdiği ve benliğinin bir parçası olarak görmeye başladığı görev ve sorumluluklarına karşı olumlu davranışlar (örneğin, iş biçimlendirme, örgütsel vatandaşlık davranışı vb.) sergileme eğilimine girme olasılıkları artmaktadır (Belk, 1988; Burke ve Reitzes, 1991; Pierce vd., 2001; Vandawalle vd., 1995).

\section{Yöntem}

\subsection{Araştırmanın Modeli ve Hipotezleri}

Gelinen noktada çalışmanın konusu olan değişkenlere yönelik yapılan çalışmalar, ortaya konan kuramlar ve söz konusu değişkenlerin yine daha önceki çalışmalarda bulgulanan ilişkileri kapsamında aşağıdaki hipotezler geliştirilmiştir:

Hipotez 1: Çalışanların mesleki özdeşleşmeleri onların iş biçimlendirme alt boyutlarını (görev, bilişsel, ilişkisel biçimlendirme) pozitif ve anlamlı olarak etkiler.

Hipotez 2: Çalışanların psikolojik sahiplenme düzeyleri onların iş biçimlendirme alt boyutların (görev, bilişsel, ilişkisel biçimlendirme) pozitif ve anlamlı olarak etkiler.

Araştırma konusu değişkenleri incelemek maksadıyla oluşturulan model ve bu modele ilişkin tüm hipotezler Şekil 1'de ayrıntılı olarak gösterilmiştir.

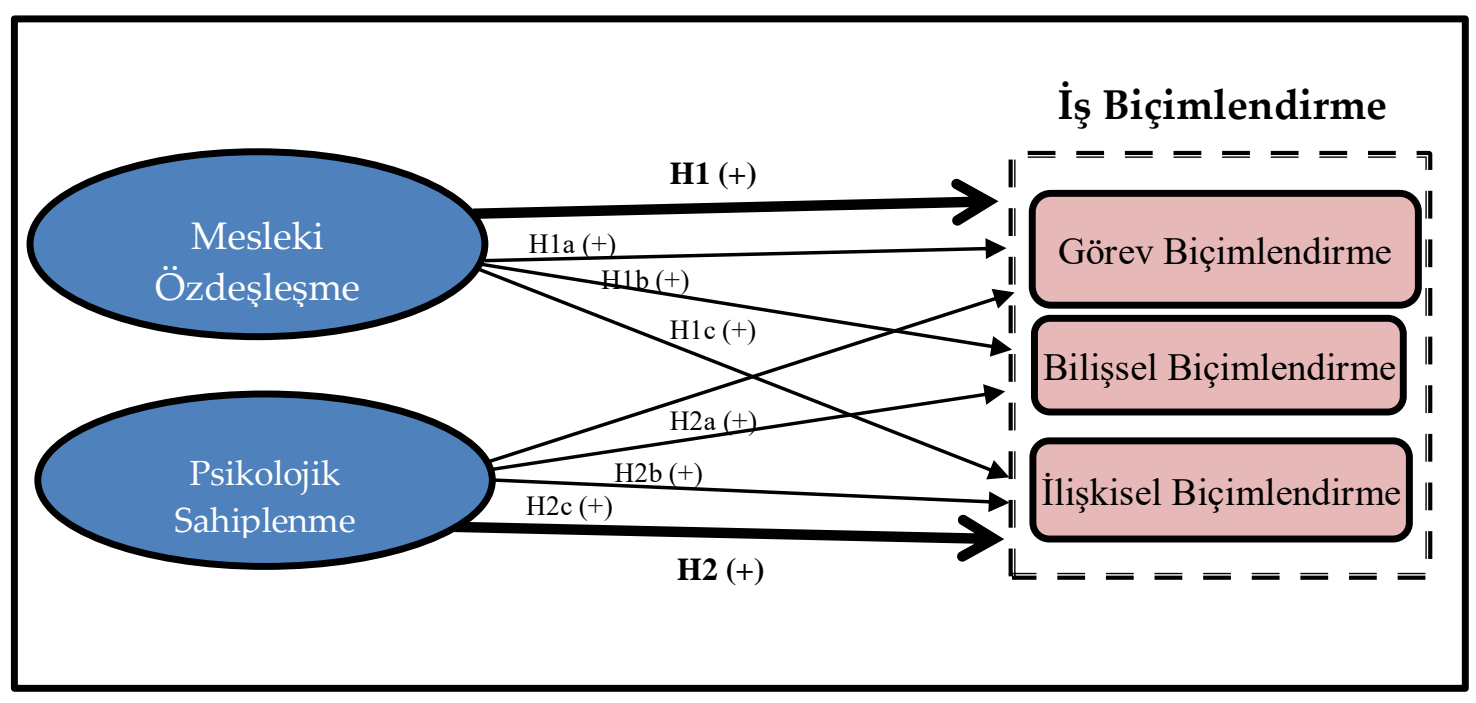

Şekil 1: Araştırma Modeli

\subsection{Evren ve Örneklem}

Araştırmamızın evreni Türkiye'deki hizmet sektörü çalışanlarıdır. Çalışmamızın örneklemini ise Ankara'da görev yapan güvenlik, eğitim, sağlık, finans gibi hizmet alanlarında çalışanlar oluşturmaktadır. Çalışmamızın nihai amacı iş biçimlendirme süreçlerinde mesleki özdeşleşme ve psikolojik sahiplenme düzeylerinin etkisini hizmet sektörü çalışanları bağlamında incelemek olduğu için tüm hizmet sektörü çalışanları araştırma evrenini oluşturmaktadır. Bu kapsamda hazırlanan anket formu hem elden dağıtılmış hem de Google Forms 
M. Begenirbaş - Y. Gökmen - R. Can Yalçın 13/2 (2021) 1127-1143

üzerinde hazırlanarak elektronik ortamda çalışanlara ulaştırılmıştır. Gönüllülük esaslı gerçekleştirilen süreçte elden ve çevrimiçi ortamda toplam 480 anket formu doldurulmuş olarak teslim edilmiş; eksik ya da özensiz doldurulanlar sonucu 16, uç analizi sonucu ise 22 form değerlendirme dışı bırakılarak toplam 442 katılımcıya ait veriler üzerinden çalışma gerçekleştirilmiştir. ${ }^{1}$ Uygulan ankete yönelik demografik değişkenler ve betimleyici istatistikler Tablo 1'de gösterilmiştir.

Table1: Demografik Değişkenler ve Betimleyici İstatistikler

\begin{tabular}{|c|c|c|c|c|c|}
\hline Değişken & Siklik & $\%$ & Değişken & Siklık & $\%$ \\
\hline 1.Cinsiyet & & & 5.Medeni Durum & & \\
\hline Kadın & 168 & 38,0 & Evli & 342 & 77,4 \\
\hline Erkek & 274 & 62,0 & Bekâr & 100 & 22,6 \\
\hline 2.Yaş & & & 6. Eğitim Düzeyi & & \\
\hline $18-29$ & 74 & 16,7 & İlköğretim & 6 & 1,4 \\
\hline $30-39$ & 128 & 29,0 & Lise & 20 & 4,5 \\
\hline $40-49$ & 168 & 38,0 & Lisans & 338 & 76,5 \\
\hline \multirow[t]{2}{*}{$50 \geq$} & 72 & 16,3 & Yüksek Lisans & 38 & 8,6 \\
\hline & & & Doktora & 40 & 9,0 \\
\hline 3. Sektör & & & 7. Çalışma Süresi (Yıl) & & \\
\hline Eğitim & 270 & 61,1 & $0-5$ & 86 & 19,5 \\
\hline Sağllk & 62 & 14,0 & $6-12$ & 78 & 17,6 \\
\hline Finans & 10 & 2,3 & $13-19$ & 210 & 47,5 \\
\hline Güvenlik & 80 & 18,1 & $20 \geq$ & 68 & 15,4 \\
\hline Diğer & 20 & 4,5 & & & \\
\hline \multicolumn{6}{|l|}{ 4. Kurum } \\
\hline Kamu & 362 & 81,9 & & & \\
\hline Özel & 80 & 18,1 & & & \\
\hline
\end{tabular}

\subsection{Veri Toplama Araçları}

Çalışmada katılımcıların mesleki özdeşleşme (MÖ) düzeyini belirlemek için Mael ve Asforth (1992) tarafından geliştirilen ve Kırkbeşoğlu ve Tüzün (2009) tarafından Türkçe'ye uyarlanan Mesleki Özdeşleşme ölçeği kullanılmıştır. Ölçeğin güvenirlik düzeyi Mael ve Asforth (1992) tarafından 0,87, Kırkbeşoğlu ve Tüzün (2009) tarafından ise 0,71 olarak hesaplanmıştır. Ölçek mesleki özdeşleşmeyi tek boyut ve altı madde ile ölçmektedir. Bu çalışmada ise güvenirlik düzeyi 0,86 olarak tespit edilmiştir.

Katılımcıların psikolojik sahiplenme (PS) düzeyi Van Dyne ve Pierce (2004) tarafından geliştirilen ölçek ile belirlenmiştir. Van Dyne ve Pierce farklı örneklemlerde ölçeğin güvenirlik düzeyini 0,87 ve 0,93 arasında bulmuşlardır. Psikolojik sahiplenme düzeyini yedi madde ile tek boyutta değerlendiren ölçeğin Türkçe'ye uyarlama çalışması Ötken (2015) tarafından gerçekleştirilmiş ve güvenirlik değeri 0,91 olarak belirlenmiştir. Ölçeğin bu çalışmada güvenirlik düzeyi 0,92 olarak hesaplanmıştır.

Son olarak, çalışmada katılımcıların iş biçimlendirme (İ̧̧B) düzeyini belirlemek için Slemp ve Vella-Brodrick (2013) tarafından geliştirilen ve güvenirlik düzeyi 0,91 olarak belirlenen ölçek kullanılmıştır. Ölçek iş biçimlendirme davranışlarını görev biçimlendirme (GB), bilişsel biçimlendirme (BB) ve ilişkisel biçimlendirme (IB) olmak üzere üç alt boyut ile değerlendirmektedir. Ölçek Kerse (2017) tarafından Türkçe'ye uyarlanmış, güvenirlik düzeyi ölçek bütünü için 0,92 , GB için 0,76 , BB için 0,86 ve İB için 0,84 olarak tespit edilmiştir. Bu çalışmada ise güvenirlik düzeyi ölçek bütünü için 0,92 , alt boyutlar için ise sırasıyla $0,94,0,86$ ve 0,93 olarak hesaplanmıştır.

\footnotetext{
${ }^{1}$ Araştırmamızda kullanılan ölçekler için MSÜ Bilimsel Araştırma ve Yayın Etiği Kurulu’ndan 25.02.2021 tarihli Etik Kurul Onay Belgesi alınmıştır.
} 


\subsection{Verilerin Analizi}

Çalışmanın istatistiksel analizlerini yapmak için SPSS 20.0, AMOS 20.0 ve EViews 10.0 paket programları kullanılmıştır. Açıklayıcı Faktör Analizi (AFA), Güvenirlilik Analizi (GA) ve Doğrulayıcı Faktör Analizi (DFA) kullanılarak üç ölçeğin faktör sonuçları, faktör yapıları ve geçerlilik ve güvenilirlikleri raporlanmıştır. Değişkenler arasındaki ilişkilerin yönü ve gücü Korelasyon Analizi (KA) ile saptanmış, demografik değişkenlerin alt grupları arasında anlamlı farklılıklar olup olmadığı $\mathrm{t}$-Testi ve Tek-Yönlü ANOVA ile test edilmiş ve bağımsız değişkenlerin (İ̧̧B, GB, BB ve İB) bağımlı değişkenler (MÖ ve PS) üzerindeki etkisini basit doğrusal regresyon analizi incelenmiştir.

\section{Bulgular}

\subsection{Açıklayıcı Faktör Analizi (AFA)}

Çalışmamızda yer alan üç ölçeğe ait örneklemin yapısal geçerliliğini kontrol etmek için Açıklayıcı Faktör Analizi (AFA) uygulanmıştır. İlk iki ölçeğin (MÖ ve PS) tüm maddeleri tek faktör altında toplandığından faktör matrisi herhangi bir yöntem ile döndürülmemiştir. Üçüncü ölçeğe (İşB) ait örnekleme AFA uygulanması sonucunda elde edilen faktörler yorumlaması daha kolay olması maksadıyla yazında yaygın olarak kullanılan Varimax yöntem ile döndürülmüştür. Ayrıca değişkenler arasındaki ilişkinin yönünü ve gücünü saptamak için KA uygulanmıştır. AFA ve KA sonuçları Tablo 2' de özet halinde gösterilmiştir.

\subsection{Güvenilirlik Analizi (GA)}

GA kapsamında Cronbach'ın Alfa Testi, araştırmalarda yer alan ölçeklerin güvenilirliğinin (içsel tutarlılığının) test edilmesi maksadıyla yazında en yaygın uygulanan metotlardan biridir. Bu katsayının 0,70 eşik değerinin üzerinde olması ölçeğin güvenilirliğine yönelik önemli bir kriter olarak kabul edilmektedir (Liu 2003; Bülbül ve Demirer, 2008). Her üç ölçeğin iç tutarlılığını sınamak için uygulanan GA sonuçları da Tablo 2'de gösterilmiştir.

Tablo 2: AFA, GA ve KA Sonuçları

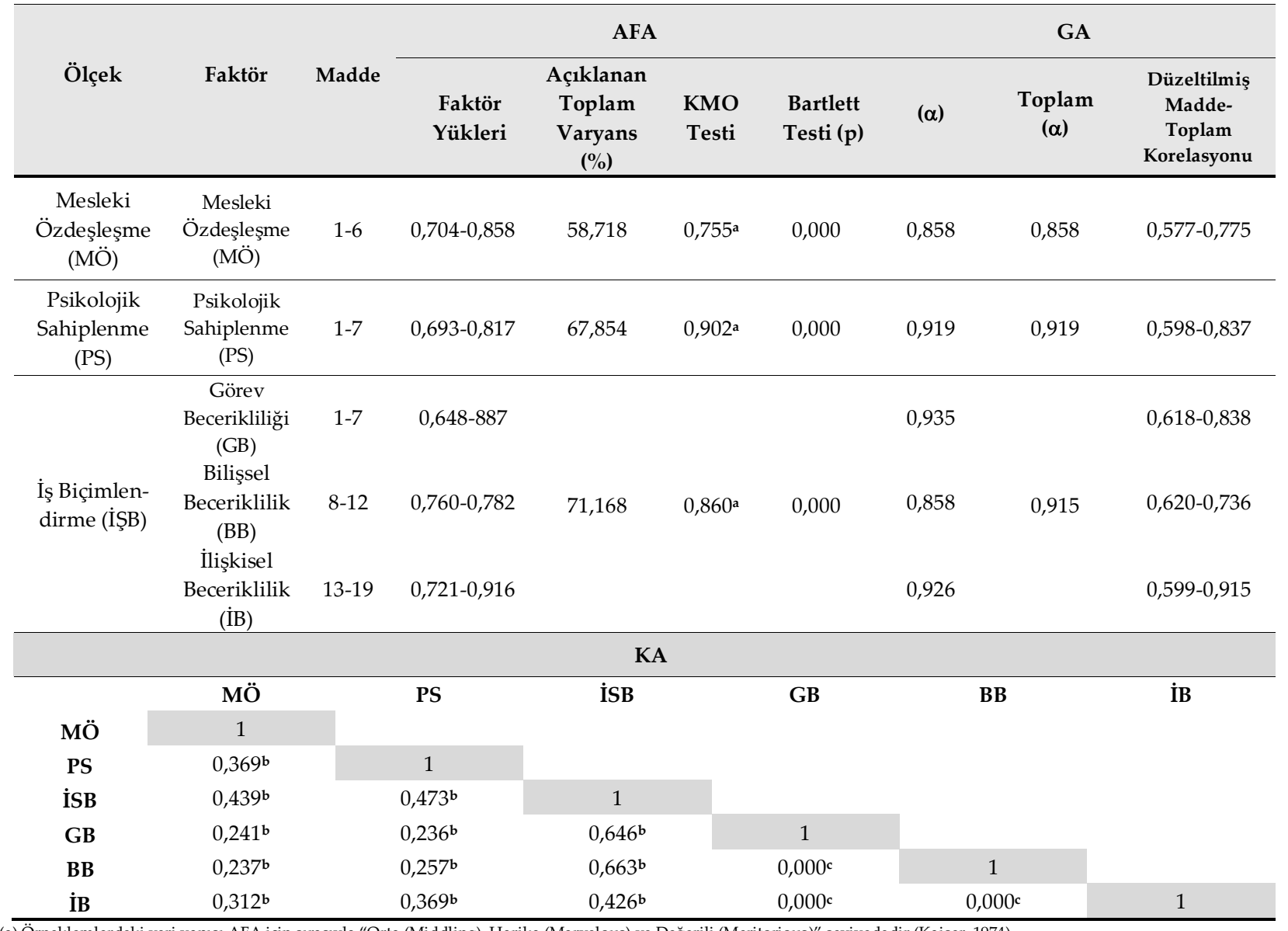

(a) Örneklemlerdeki veri yapısı AFA için sırasıyla “Orta (Middling), Harika (Marvelous) ve Değerili (Meritorious)" seviyededir (Kaiser, 1974).

(b) Korelasyon katsayıları $\alpha=0.05$ anlamlılık düzeyine göre anlamlıdır.

(c) Değişkenler arasında korelasyon katsayısı hesaplanırken AFA sonucu oluşan ve aynı ölçekte yer alan ilgili faktörlerin faktör skorları kullanıldığından (Johnson ve Wichern, 2002) bu faktörler (değişkenler) arasında anlamlı bir korelasyon bulunmamaktadır. 
Tablo 2'deki sonuçlar değerlendirildiğinde, tüm Cronbach'ın Alfa değerleri eşik değerinden $(0,70)$ büyük olduğu görülmektedir. (Ravichandran ve Rai, 1999; Jonsson 2000; Hair vd, 2014). Ayrıca, her üç ölçeğe ait maddelerin düzeltilmiş madde toplam korelâsyon değerlerinin tamamımın öngörülen eşik değerinin $(0,20)$ üzerinde olduğu saptanmıştır. (Streiner ve Norman, 2003). KA sonuçlarına göre İŞB ile GB, BB ve İB değişkenleri arasında orta düzeyde; PS değişkeni ile GB, BB ve İB arasında zayıf düzeyde ve İşB arasında ise orta düzeyde; MÖ ile İŞB arasında orta düzeyde, PS, GB, BB ve İB arasında ise zayıf düzeyde korelasyon bulunmaktadır (Schober vd., 2018).

\subsection{Doğrulayıcı Faktör Analizi (DFA)}

Çalışmada yer alan ölçeklerin faktör yapısını incelenmek için AFA'dan elde edilen sonuçlara en yüksek olabilirlik (maximum likelihood) kestirim yöntemi kullanılarak DFA yapılmıştır. Üç örneklemin DFA sonuçları Tablo 3'te ayrıntılı olarak sunulmuştur.

Tablo 3: DFA Sonuçları

\begin{tabular}{|c|c|c|c|c|c|c|c|}
\hline & Parametreler & Kisalt. & $\begin{array}{c}\text { Mükemmel } \\
\text { Uyum Eşik } \\
\text { Değeri }\end{array}$ & $\begin{array}{l}\text { Kabul Edilebilir } \\
\text { Uyum Aralığı }\end{array}$ & MÖ & PS & İşB \\
\hline \multirow{7}{*}{ 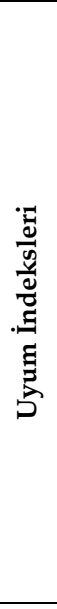 } & $\begin{array}{l}\text { Uyum İyiliği İndeksi(Goodness } \\
\text { of Fit Index) }\end{array}$ & GFI & $\geq 0.95^{a}$ & $0.90 \leq G F I \leq 0.95^{a}$ & 0,991 & 0,991 & 0,931 \\
\hline & $\begin{array}{l}\text { Düzeltilmiş Uyum İndeksi } \\
\text { (AdjustedGoodness of Fit Index) }\end{array}$ & AGFI & $\geq 0.90^{a, b}$ & $0.85 \leq A G F I \leq 0.90^{a}$ & 0,968 & 0,962 & 0,893 \\
\hline & $\begin{array}{l}\text { Karşılaştırmalı Uyum İndeksi } \\
\text { (ComparativeGoodness of Fit } \\
\text { Index) }\end{array}$ & CFI & $\geq 0.97^{a}$ & $0.95 \leq C F I \leq 0.97^{a}$ & 0,995 & 0,997 & 0,971 \\
\hline & $\begin{array}{l}\text { Normalleştirilmemiş Uyum } \\
\text { İndeksi(Non-normal Fit Index) }\end{array}$ & NNFI & $\geq 0.97^{a, b}$ & $0.90 \leq N N F I \leq 0.97^{a, b}$ & 0,987 & 0,990 & 0,960 \\
\hline & $\begin{array}{l}\text { Normalleştirilmiş Uyum İndeksi } \\
\text { (Normal Fit Index) }\end{array}$ & NFI & $\geq 0.95^{\mathrm{a}}$ & $0.90 \leq N F I \leq 0.95^{a}$ & 0,990 & 0,993 & 0,955 \\
\hline & $\begin{array}{l}\text { Yaklaşık Hataların Ortalama } \\
\text { Karekökü(Root-Square- } \\
\text { MeanError of Approximation) }\end{array}$ & RMSEA & $\leq 0.05^{a, c}$ & $0.05 \leq R M S E A \leq 0.10^{a}$ & 0,050 & 0,049 & 0,062 \\
\hline & $\begin{array}{l}\text { Minimum Tutarsızlık } \\
\text { (Minimum Discrepancy) }\end{array}$ & CMIN/SD & $\leq 2^{\mathrm{a}, \mathrm{d}}$ & $2 \leq C M I N / S D \leq 3^{a}$ & 2,087 & 2,039 & 2,683 \\
\hline \multirow{4}{*}{ 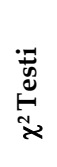 } & Örneklem Boyutu & $\mathbf{N}$ & & & & 442 & \\
\hline & Serbestlik Derecesi & SD & & & 6 & 7 & 123 \\
\hline & $\chi^{2}$ Değeri & $\chi^{2}$ & & & 12,520 & 14,271 & 329,990 \\
\hline & Anlamlılı̆̆ın Kesin Düzeyi & $\mathbf{P}$ & $\geq 0,05^{\mathrm{a}}$ & $0.01 \leq p \leq 0.05^{\mathrm{a}}$ & $p_{1}=0,051$ & $\mathrm{p}_{2}=0,047$ & $\mathrm{p}_{3}=0,012$ \\
\hline
\end{tabular}

(a): Schermelleh, Moosbrugger and Müler (2003); (b): Hu and Bentler (1995); (c): Steiger (1990); (d): Marsh and Hocevar (1985); Ullman, (2001). Mükemmel uyum eşik değerini sağlayan uyum indeksi değerleri italik ve kalın gösterilmiştir. Diğer değerler kabul edilebilir uyum aralığındadır.

Tablo 3'deki DFA sonuçlarını incelendiğinde; ilk örnekleme ait $\chi^{2}$ sınamasında, $\mathrm{p}_{1}=0,051 \geq 0,05$ ve son iki örnekleme ait $\chi^{2}$ sinamasında $\mathrm{p}_{2}=0,047$ ve $\mathrm{p}_{3}=0,012$ değerlerinin 0,01 ve 0,05 aralığında olduğu görülmektedir. Aslında araştırmacılar tarafından $\chi^{2}$ sınamasının örneklem büyüklüğüne çok duyarlı olduğu ve bu nedenle örneklem boyutu büyük olduğu durumda istatistiksel olarak anlamlı bir $\chi^{2}$ değeriyle sonuçlanabileceği ifade edilmiştir (Bollen, 1989; Lance\&Vandenberg, 2001). Bu nedenle, çoğu araştırmacı arasındaki ortak uygulama, $\chi^{2}$ değerinin makul olup olmadığını görmek ve modelin gücünü diğer uyum indekslerine dayandırmaktır (Vandenberg, 2006). Bu kapsamda; analiz sonuçlarına göre tüm uyum indekslerinin kabul edilebilir uyum aralığı içinde ve çoğu uyum indeks değerlerinin ise çok iyi uyum düzeyinde olduğu görülmektedir (Schermelleh vd., 2003). Genel olarak, GFI, AGFI, NFI, NNFI ve CFI indeks değerlerinin 0,90'a yakın ve üzerinde, RMSEA indeks değerinin ise 0,10'dan küçük olması, modellerin gerçek veriler ile uyumu için kabul edilebilir kriterler olarak tanımlanabilir (Anderson ve Gerbing, 2004; Becker vd., 2004). Sonuç olarak, elde edilen uyum indeksleri değerleri göz önünde bulundurulduğunda, örneklemlere uygulanan ölçeklere yönelik faktör yapısının kabul edilebilir olduğu düşünülebilir.

\subsection{Farklılıkların Analizi}

Demografik değişkenlere ilişkin alt gruplarının ortalamaları arasında istatistiksel olarak anlamlı farklılık olup olmadığını belirlemek için t-Testi ve Tek-Yönlü ANOVA analiz yapılmıştır. Bu testlerin sonuçları Tablo 5'te gösterilmektedir. 
M. Begenirbaş - Y. Gökmen - R. Can Yalçın 13/2 (2021) 1127-1143

Table 5: Bağımsız Örneklem t-Testi ve ANOVA Testi Sonuçları

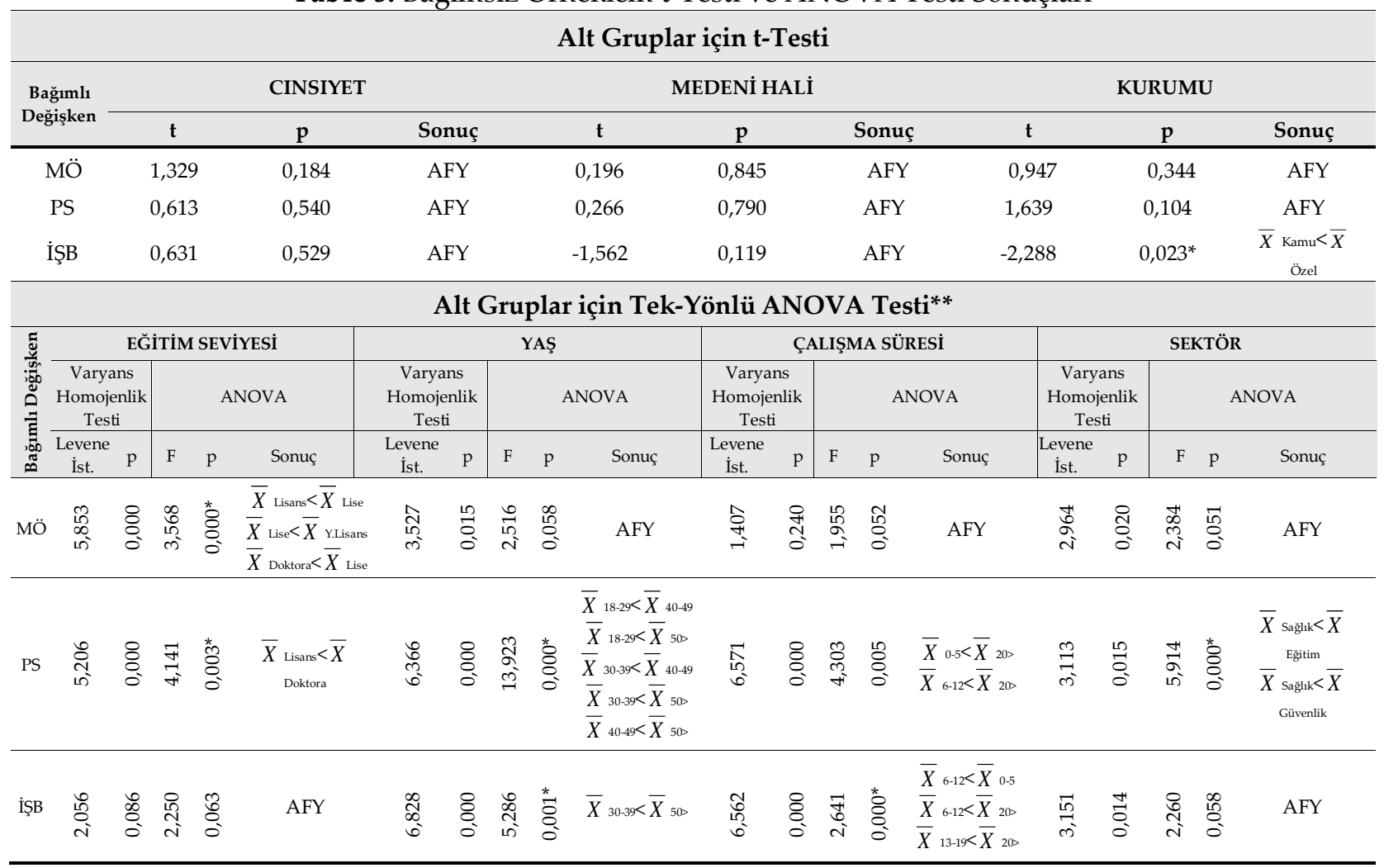

\section{AFY: Anlamlı Fark Yok}

$\left(^{*}\right)$ Alt gruplar arasındaki ortalama farklılıklar $\alpha=0.05$ düzeyinde istatistiksel olarak anlamlıdır.

(**) Alt gruplarda eşit olmayan katılımcı sayısını olduğu durumlarda çoklu karşılaştırmalar yapmak için eşit varyans varsayımı altında Scheffé testi ve Hochberg'in GT2 testi (Bryman and Cramer, 2002: 174; Field, 2009: 374) eşit varyans koşulu olmadığında ise Games- Howell (Field, 2009: 374) testi kullanılmıştır

Tablo 5'teki sonuçlar incelendiğinde, İŞB değişkenine göre katılımcıların çalıştığı kuruma ilişkin alt grupları ortalamaları arasında anlamlı bir fark olduğu görülmektedir. Öte yandan, eğitim seviyesi alt grup ortalamalarında MÖ değişkenine göre anlamlı farklılıklar meydana gelmektedir. Yaş değişkeni alt grupları ortalamaları ise PS ve İŞB değişkenleri açışından anlamlı farklılıklar ortaya koymaktadır. Çalışma süresi değişkenin alt boyutları ortalamaları ele alındığında, PS ve İ̧̧B değişkenlerine göre anlamlı farklılıklar ortaya çıkmaktadır. Sektör değişkenin alt boyutlarının ortalamaları göz önüne alındığında sadece PS değişkeni açısından anlamlı farklılıklar oluştuğu görülmektedir.

\subsection{Değişkenler Arası İlişkilerin/Etkilerin Analizi}

Bağımsız değişkenler (MÖ ve PS) ile bağımlı değişkenler (İ̧B, GB, BB ve İB) arasındaki ilişkileri ve nedensellikleri saptamak için, AFA'dan elde edilen faktör puanları kullanılarak regresyon varsayımları göz önünde bulundurularak basit doğrusal regresyon analizi yapılmıştır (Johnson ve Wichern, 2002). Regresyon analizi ve hipotez sonuçları özet olarak Tablo 5 'te gösterilmiştir.

Tablo 5: Regresyon Analizi Sonuçları a,b

\begin{tabular}{|c|c|c|c|c|c|c|c|c|c|c|c|c|}
\hline \multirow[b]{2}{*}{$\begin{array}{c}\text { Model } \\
\text { No. }\end{array}$} & \multirow[b]{2}{*}{$\begin{array}{c}\text { Bağımlı } \\
\text { Değişken }\end{array}$} & \multirow[b]{2}{*}{$\mathbf{R}^{2}$} & \multirow[b]{2}{*}{$\begin{array}{c}\text { Düzel } \\
\text { t. } \\
\mathbf{R}^{2}\end{array}$} & \multirow[b]{2}{*}{ SH } & \multirow[b]{2}{*}{$\mathbf{F}$} & \multirow[b]{2}{*}{$\mathbf{p}$} & \multicolumn{4}{|c|}{ Standartlaştırıl- } & \multirow[b]{2}{*}{$\begin{array}{c}\text { Hipotez } \\
\text { No. }\end{array}$} & \multirow[b]{2}{*}{$\begin{array}{l}\text { Hipotez } \\
\text { Sonucu }\end{array}$} \\
\hline & & & & & & & $\begin{array}{l}\text { Bağımsız } \\
\text { Değişken }\end{array}$ & $\begin{array}{c}\text { mamış } \\
\text { Katsayılar } \\
b_{i}\end{array}$ & $\mathbf{t}$ & $\mathrm{p}$ & & \\
\hline 1 & İŞB & 0,192 & 0,190 & 0,899 & 104,749 & $0,000^{c}$ & \multirow{4}{*}{ MÖ } & 0,748 & 10,235 & $0,000^{c}$ & H1 & KABUL \\
\hline 2 & GB & 0,058 & 0,046 & 0,972 & 27,117 & $0,001^{\mathrm{c}}$ & & 0,241 & 5,207 & $0,000^{c}$ & H1a & KABUL \\
\hline 3 & BB & 0,056 & 0,054 & 0,973 & 26,106 & $0,000^{c}$ & & 0,237 & 5,109 & $0,000^{c}$ & H1b & KABUL \\
\hline 4 & İB & 0,097 & 0,095 & 0,951 & 47,492 & $0,000 \mathrm{c}$ & & 0,312 & 6,891 & $0,000^{c}$ & H1c & KABUL \\
\hline 5 & İŞB & 0,223 & 0,222 & 0,882 & 126,499 & $0,000^{\mathrm{c}}$ & \multirow{4}{*}{ PS } & 0,806 & 11,247 & $0,000^{c}$ & H2 & KABUL \\
\hline 6 & GB & 0,056 & 0,054 & 0,972 & 26,028 & $0,000 \mathrm{c}$ & & 0,236 & 5,102 & $0,000 \mathrm{c}$ & H2a & KABUL \\
\hline 7 & BB & 0,066 & 0,064 & 0,968 & 31,077 & $0,000^{c}$ & & 0,257 & 5,575 & $0,000^{c}$ & $\mathrm{H} 2 \mathrm{~b}$ & KABUL \\
\hline 8 & İB & 0,136 & 0,134 & 0,930 & 69,367 & $0,000^{c}$ & & 0,369 & 8,329 & $0,000^{c}$ & $\mathrm{H} 2 \mathrm{c}$ & KABUL \\
\hline
\end{tabular}

(a) One-Sample Kolmogorov-Smirnov Normallik Testi sonuçlarına göre regresyon denklemlerinin artıkları (residuals) normal dağıllmıştır ( $p>\alpha=0,05)$.

(b) White Homoscedasticity Test sonuçlarına göre regresyon modellerinde değişen varyans problem yoktur. $(\mathrm{p}>0,05)$.

(c) Regresyon modeli ve bağımsız değişken katsayıları $\alpha=0.05$ anlamlılık düzeyinde anlamlıdır. 
Tablo 5 incelendiğinde regresyon analizi $\mathrm{F}$ testi sonuçlarına göre bütün modellere (1-8) ilişkin $p$ değerleri<0.05 olduğundan, \%95 güvenirlilik düzeyinde söz konusu modellerin tümüyle anlamlı olduğuna karar verilebilir. Diğer yandan, tüm regresyon modellerinde yer alan bağımsız değişkenlerin katsayılarının $t$ testi sonuçlarına göre $\mathrm{p}$ değerleri<0,05 olduğundan $\alpha=0.05$ anlamlılık düzeyinde anlamlı olduğu ifade edilebilir.

\section{Sonuç ve Tartışma}

Günümüzdeki küresel ekonomik şartlar ve bilişim teknolojilerindeki hızlı gelişmeler iş dünyasına da her zamankinden daha hızlı bir değişim ve uyum zorunluluğu şeklinde yansımaktadır. Öyle ki çalışma kavramının birçok durumda küresel boyutta gerçekleşmesi, sanal çalışma mekanizmasının yaygınlaşması ve kendi kendini yöneten iş ekiplerinin ortaya çıkışı örgütleri çok daha karmaşık ve esneklik temelli bir yaklaşıma uyum sağlamak zorunda bırakmıştır. Örgütlerde yürütülen işler, sürekli değişen roller, görevler ve projeler ile birleştiğinde daha dinamik hale gelmiş (Grant ve Parker, 2009) ve yöneticiler işyerinde ortaya çıkan talepleri ve fırsatları değerlendirirken, çalışanlarının işlerinin doğasındaki değişiklikleri ya da beklenmedik gelişmeleri mevcut duruma uyumlandırmalarına ve işlerin yürümesini sağlama güçlerine giderek daha fazla güvenmek zorunda kalmışlardır (Demerouti, 2014). Diğer bir ifade ile, hızla değişen iş dünyasında örgüt yöneticilerinin temel amacı çevresel değişimlere uyum sağlayarak oluşabilecek talepleri proaktif şekilde karşılayabilecek çalışanlara sahip olabilmektir (Fayganoğlu, 2019a). Bu bağlamda çalışmamız genel olarak belirsizlik içeren ve hızla değişen günümüz dünyasında çalışanların mesleki özdeşleşme ve psikolojik sahiplenme düzeylerinin iş biçimlendirme davranışlarında etkili olduğunu ortaya koymuştur.

Araştırma bulguları bağlamında ilk olarak, yazında doğrudan mesleki özdeşleşme ve iş biçimlendirme davranışlarının ilişkisini ele alan bir çalışmaya rastlanılmamasına rağmen örgütsel özdeşleşme ve iş biçimlendirme davranışları arasındaki ilişkiyi ele alan sınırlı sayıda çalışmaya ulaşılmıştır. Örgütleri ile kendilerini özdeşleştiren çalışanların hâlihazırda meslekleri ile de bu şekilde bir özdeşleşme geliştirmiş olmaları gerektiği göz önünde bulundurulursa söz konusu sınırlı sayıdaki çalışmanın da sonuçlarımızın değerlendirilmesinde ışık tutacağı düşünülmektedir. Bu bağlamda, Wang vd. (2017a) dönüşümcü liderliğin iş biçimlendirme ile ilişkisinde örgütsel özdeşleşmenin aracılık rolü ile ilgili yaptıkları çalışmalarında örgütsel özdeşleşmenin iş biçimlendirme davranışını pozitif ve anlamlı olarak etkilediğini ortaya koymuşlar ve iş biçimlendirmede özdeşleşme düzeyi yüksek çalışanların herhangi bir liderlik algısı gerektirmeden doğal olarak iş biçimlendirme davranışlarında daha yüksek olduğu sonucuna varmışlardır. Dolayısıyla mesleki özdeşleşmenin iş biçimlendirme davranışlarını etkilediğini ortaya koyan bu çalışma bulguları Wang vd. (2017a)'nin sonuçlarını desteklemektedir. Diğer yandan Kılıç ve arkadaşları (2020) ile Bacaksız ve arkadaşları (2017) ise, örgütleri tarafından iş biçimlendirme fırsatı sunulan çalışanların kendilerini örgütleri ile özdeşleştirme düzeylerinin yüksek olduğunu tespit etmişlerdir. Dolayısıyla özdeşleştirme ve iş biçimlendirme davranışları arasındaki ilişkinin tek yönlü olmaktan öte aslında karşılıklı bir etkileşim şeklinde gerçekleştiği değerlendirilmektedir.

İkinci olarak, psikolojik sahiplenme ve iş biçimlendirme ilişkisini inceleyen çok az sayıda çalışma bulunmaktadır. Wang ve arkadaşları (2018) örgütleri tarafından sağlanan iş biçimlendirme fırsatının çalışanların hissettikleri psikolojik sahiplenme düzeyini pozitif etkilediği sonucuna ulaşmışlardır. Benzer şekilde Shenavar (2017) ile Wang ve arkadaşları (2017b) da psikolojik sahiplenmenin iş biçimlendirme ve iş tatmini arasındaki ilişkide aracılık etkisine sahip olduğunu tespit etmişlerdir. Bu çalışmada ise psikolojik sahiplenmenin iş biçimlendirme davranışlarını pozitif olarak etkileyen bir değişken olduğu sonucuna varılmıştır. Dolayısıyla psikolojik sahiplenme ve iş biçimlendirme davranışlarının da aslında karşılıklı olarak birbirini etkileyen değişkenler olduğu düşünülebilir.

Demografik faktörlerin değişkenler ile ilişkine bakıldığında bazı hususlar dikkat çekmektedir. Öncelikle analiz sonuçlarına göre özel sektör çalışanlarının iş biçimlendirme ortalamaları kamu sektöründe çalışanlardan daha yüksek olduğu görülmektedir. Bu durumun özel sektörde faaliyet gösteren örgütlerin kamu örgütlerine nazaran daha yüksek performans odaklı olmalarından kaynaklanabileceği değerlendirilmektedir. Dolayısıyla özel sektör çalışanlarının örgütün performans beklentisini karşılayabilmek için yaptıkları işi kendi iş yapma tercihlerine göre biçimlendirerek karşılamaya çalışmaları omuhtemel 
M. Begenirbaş - Y. Gökmen - R. Can Yalçın 13/2 (2021) 1127-1143

görünmektedir. İkinci olarak, psikolojik sahiplenme düzeyinin en yüksek olduğu mesleğin öğretmenlik olduğu görülmektedir. Sağlık ya da güvenlik sektörü çalışanlarının işlerini yaparken çok farklı kesimlerden insanlarla etkileşim içine girmek durumundadırlar. Diğer yandan öğretmenler ise temel olarak öğrencilerle etkileşim halindedir ve ülkenin geleceğini şekillendirme gibi duygusal boyutu olan bir mesleği icra etmektedirler. Dolayısıyla öğretmenliğin özü itibariyle psikolojik sahiplenmeyi barındırması gereken bir meslek olduğu değerlendirilmektedir.

Çalışma bulgularına göre bir takım saptamalarda bulunulabilir. Bu kapsamda, iş biçimlendirme yaklaşımı yöneticiler tarafından gerçekleştirilen iş tasarımının değerini azaltmaz, sadece çalışanların mevcut tasarımlar üzerinde değişiklik yapabilme fırsatının önemine işaret eder (Berg, Dutton ve Wrzesniewski, 2007). Öyle ki doğru uygulandığı zaman, iş biçimlendirme çalışanlar ve aynı zamanda örgütler için bazı kolaylıklar sağlayabilir. Zira her birey farklıdır ve bir örgütün her bir çalışan için ayrı ayrı optimal iş tasarımı oluşturabilmesi oldukça güçtür. Dolayısıyla örgütlerin çalışanlarına yaptırdıkları görevlere yönelik iş biçimlendirmelerine fırsat sağlayabilecek bir alan bırakması hem çalışanlar hem de örgütler için faydalı sonuçlar üretebilir. Yaptıkları işleri biçimlendirme olanağı bulabilen çalışanlar hem kendi motivlerine, güçlerine ve isteklerine uygun bir bağlam yaratarak iş yeri refahı sağlarken hem de örgüt amaçlarına daha istekli şekilde hizmet edebilirler.

Sektör yöneticilerinin çalışanların mesleki özdeşleşme ve işlerine yönelik psikolojik sahiplenmelerini sağlayacak uygulamalar yapmaları ve davranış biçimleri sergilemeleri uygun olacaktır. Böylelikle çalışanlar yaptıkları işlerin sorumluluğunu alarak ve görevlerini benimseyerek işlerini daha iyi yapma, üretken ve verimli olma anlamında iş biçimlendirmelerini örgüt yararına yapabilirler.

Bu çalışma bazı kısıtlar çerçevesinde gerçekleştirilmiştir. Öncelikle çalışma sadece Türkiye'de ve hizmet sektöründe görev yapan çalışanlardan elde edilen verilerle gerçekleştirilmiştir. İleride yapılacak çalışmaların kültürel bağlam ve meslek grupları bakımından daha geniş örneklemler üzerinden gerçekleştirilmesi sonuçların genellenebilmesi açısından faydalı olacaktır. İkinci olarak, çalışmamız katılımcıların ölçeklerin uygulandığı andaki düşüncelerini yansıtmaktadır. Farklı zamanlarda yapılacak çalışmalarla sonuçların geliştirilebileceği düşünülmektedir. Ayrıca, çalışmamızda kullanılan veriler sadece anket yoluyla elde edilmiştir ve gelecekte yapılacak mülakat gibi nitel araştırma yöntemleri ile konu ile ilgili çeşitlendirilmiş sonuçlarla yazının zenginleştirilebileceği değerlendirilmektedir.

Son olarak, iş biçimlendirme ve iş biçimlendirme davranışları ile mesleki özdeşleşme ve psikolojik sahiplenme arasındaki ilişkiyi inceleyen sınırlı sayıda çalışma bulunmakta ve bu çalışmaların da farklı bakışlarla yapılandırıldığı ve farklılaşan sonuçlar ortaya koyduğu görülmektedir. Dahası söz konusu değişkenler arasındaki ilişkinin tek yönlü mü yoksa karşılıklı olarak mı gerçekleştiği konusunda genelleme yapabilmek mümkün görünmemektedir. Dolayısıyla söz konusu değişkenler ile gelecekte farklı bağlamlarda yürütülecek çalışmaların yazına değerli katkılar sağlayabileceği söylenebilir. 


\section{KAYNAKÇA}

Akın, A., Sarıçam, H., Kaya Ç. ve Demir, T. (2014). Turkish Version of Job Crafting Scale (JCS): The Validity and Reliability Study. International Journal of Educational Researchers, 5(1), 10-15.

Anderson, J. ve Gerbing, D. (2004). The effect of sampling error on convergence, improper solutions, and goodness-of-fit indices for maximum likelihood confirmatory factor analysis, Psychometrika, 49(2), 155173.

Ashforth, B. E. ve Mael, F. (1989). Social Identity Theory and The Organizations, Academy of Management Review, 14, 20-39.

Ashforth, B.E., Harrison, S.H. ve Corley, K.G. (2008). Identification in Organizations: An Examination of Four Fundamental Questions, Journal of Management, 34, 325-374.

Ashforth, B.E., Joshi, M., Anand, V., O'Leary-Kelly, A.M. (2013). Extending the expanded model of organizational identification to occupations. Journal of Applied Social Psychology, 43, 2426-2448.

Avey, J.B., Avolio, B.J., Crossley, C.D., Luthans, F. (2009). Psychological Ownership: Theoretical Extensions, Measurement and Relation to Work Outcomes, Journal of Organizational Behavior 30, 173-191.

Bacaksiz, F. E., Tuna, R., \& Seren, A. K. H. (2017). The relationships between organisational identification, job performance, and job crafting: A study among nurses. International Journal of Caring Sciences, 10, 251259

Bamber, E.M. ve Iyer, V.M. (2002). Big 5 Auditors' Professional and Organizational Identification: Consistency Or Conflict?, Auditing: A Journal of Practice \& Theory, 21, 21-38.

Becker, A., Hagenberg, N., Roessner, V., Woerner, W. veRothenberger, A. (2004). Evaluation of the selfreported SDQ in a clinical setting: Do self-report tell us more than ratings by adult informants? European Child and Adolescent Psychiatry, 13(2), 17-24.

Belk, R.W. (1988). Possessions and The Extended Self, Journal of Consumer Research 15, 139-168.

Bell, N. E., \& Staw, B. M. (1989). People as sculptors versus sculptor: the roles of personality and personal control in organizations. In M. B. Arthur, D. T. Hall, \& B. S. Lawrence (Eds.), Handbook of career theory (pp. 232- 251). New York: Cambridge University Press.

Berg, J. M., Dutton, J. E., \& Wrzesniewski, A. (2007). What is job crafting and why does it matter?Retrieved form the website of Positive Organizational Scholarship on April, 15, 2020.

Berg, J. M., Grant, A. M. ve Johnson, V. (2010). When Callings are Calling: Crafting Work and Leisure in Pursuit of Unanswered Occupational Callings. Organization Science, 21(5), 973-994.

Berg, J. M., Dutton, J. E. ve Wrzesniewski, A. (2013). Job Crafting and Meaningful Work. B. J. Dik, Byrne, Z. S. ve Steger, M. F. (Ed.). Purpose and Meaning in the Workplace içinde. Washington DC, American Psychological Association Books: 81-104.

Bollen, K. A. (1989). Structural equations with latent variables. New York: John Wiley.

Bora, D. (2019). Örgütlerde Özerklik ve Vatandaşlık Davranışı İlişkisinde Psikolojik Sahiplenmenin Aracıllk Rolü: Nevşehir Otel İşletmeleri Örneği, Nevşehir Hacı Bektaş Veli Üniversitesi Sosyal Bilimler Enstitüsü, Doktora Tezi.

Brown, G, Pierce, J.L, Crossley, C. (2014) Toward an Understanding of the Development of Ownership Feelings. Journal of Organizational Behavior, 35, 318-338.

Bryman, A., \& Cramer, D. (2002). Quantitative data analysis with SPSS release 10 for Windows: A guide for social scientists. Routledge.

Buchko, A.A. (1992), "Effects of Employee Ownership on Employee Attitudes a Test of Three Theoretical Perspectives", Work and Occupations, 19(1), 59-78. 
M. Begenirbaş - Y. Gökmen - R. Can Yalçın 13/2 (2021) 1127-1143

Burke P.J., Reitzes, D.C. (1991). An Identity Theory Approach to Commitment, Social Psychology Quarterly, 54, 239-251.

Bülbül, H. \&Demirer, Ö. (2008). Hizmet Kalitesi Ölçüm Modelleri SERVQUAL ve SERPERF'in Karşılaştırmalı Analizi. Selçuk Üniversitesi Sosyal Bilimler Enstitüsü Dergisi, 20, 181-198.

Büyüköztürk, Ş. (2007). Sosyal Bilimler İçin Veri Analizi El Kitabı, Ankara: Pegem A Yayıncılık.

Demerouti, E. (2014). Design your own job through job crafting. European Psychologist, 19, 237-247.

Dittmar, H. (1992). The Social Psychology of Material Possessions: To Have is to Be. New York: St. Martin's Press.

Doğan, A. (2020). Mesleki Özdeşleşme İle Tükenmişlik İlişkisinde İş Yükü Algısı Ve Psikolojik Dayanıklılığın Aracı Rolü, Doktora Tezi Başkent Üniversitesi Sosyal Bilimler Enstitüsü.

Fayganoğlu, P. (2019). Bilgi Yoğun Örgütler Öznesinde Örgütsel Güç ve Örgüt İçi Koalisyon Kavramları. Gazi İktisat ve İşletme Dergisi, 5(2), 119-138.

Fayganoğlu, P. (2019a). Örtük Bilgi Ve Örtük Bilgi Paylaşımının Örgütler İçin Enilikçilik Ve Hayatta Kalma Açısından Önemi. Journal of International Social Research, 12(63).

Field, A. (2009). Discovering Statistics Using SPSS, Third Edition.

Florkowski, G. W. (1987), “The Organizational Impact of Profit Sharing”, Academy of management Review, 12(4), 622-636.

Ghitulescu, B. E. (2007). Shaping Tasks and Relationships at Work: Examining the Antecedents and Consequences of Employee Job Crafting (Yayınlanmamış Doktora Tezi). Pittsburgh, ABD, University of Pittsburgh.

Gillet, N., Colombat, P., Michinov, E., Pronost, A.M. \& Fouque-Reau, E. (2013). Procedural Justice, Supervisor Autonomy Support, Work Satisfac-Tion, Organizational İdentification And Job Performance: The Mediating Role Ofneed Satisfaction And Perceived Organizational Support, Journal of AdvancedNursing 69(11), 2560-2571.

Grant, A. M., \& Parker, S. K. (2009). Redesigning work design theories: The rise of relational and proactive perspectives. The Academy of Management Annals, 3, 317-375.

Hair, J. F., Black, W. C., Babin, B. J., Anderson, R. E., \&Tatham, R. L. (2014) Multivariate Data Seventh Edition, Pearson Education Limited. USA.

Hirschi A. (2012). Callings and Work Engagement: Moderated, Occupational Identity and Occupational SelfEfficacy, Journal of Counseling Psychology, 59(3), 479-485.

Hu, L.T. ve Bentler, P.M. (1995). Evaluating model fit, içinde: R. H. Hoyle (Ed.), Structural equation modeling: Concepts, issues, and applications. CA: Sage.

Hur, W. M., Shin, Y., Rhee, S. Y. ve Kim, H. (2017). Organizational Virtuousness Perceptions And Task Crafting: The Mediating Roles Of Organizational Identification And Work Engagement, Career Development International, 22(4), 436-459.

Ibarra, H. (1999). Provisional Selves: Experimenting with Image And Identity in Professional Adaptation, Administrative Science Quarterly, 44, 764-791.

Johnson, Richard A., and Dean W. Wichern. (2002). Applied Multivariate Statistical Analysis: Vol. 5 No. 8. Upper Saddle River, NJ: Prentice Hall.

Jonsson, Patrik. 2000. "An Empirical Taxonomy of Advanced Manufacturing Technology." International Journal of Operations \& Production Management 20(12): 1446-1474.

Kaiser, H.F., 1974. An index of factorial simplicity.Psychometrika. 39 (1), 31-36.

Katz, D. and R. L. Kahn, (1966) the Social Psychology of Organizations, New York: John Wiley \& Sons. 
M. Begenirbaş - Y. Gökmen - R. Can Yalçın 13/2 (2021) 1127-1143

Kerse, G. (2017). “İşs Becerikliliği (Job Crafting) Ölçeğini Türkçe’ye Uyarlama ve Duygusal Tükenme İle İlişkisini Belirleme". İşletme Araştırmaları Dergisi, 9 (4), 283-304.

Kılıç, E., Tatar, B., \& Erdil, O. (2020). The relationship between job crafting and organizational identification: The mediating role of affective well-being. Business and Economics Research Journal, 11(1), 201-212.

Kırkbeşoğlu, E., Tüzün, İ.K. (2009). Bireycilik - Toplulukçuluk İkileminde Mesleki Özdeşleşme Ve Örgütsel Özdeşleşme Ayrımı, Organizasyon Ve Yönetim Bilimleri Dergisi Cilt 1(1): 1-8.

Kira, M., F. van Eijnatten, M. ve Balkin, D.B. (2010). Crafting Sustainable Work: Development of Personal Resources. Journal of Organizational Change Management, 23(5), 616-632.

Kirkendall, C. D. (2013). Job Crafting: The Pursuit Of Happiness At Work. (Doctor Of Philosophy), Wright State University Graduate School, Wright State University.

Kreiner, G.E. ve Ashforth, B.E. (2004). Evidence Toward An Expanded Model Of Organizational Identification, Journal of Organizational Behavior, 25, 1-27.

Kroon, D.P. ve Noorderhaven, N.G. (2018). The Role of Occupational Identification During Post-Merger Integration, Group \& Organization Management, 43(2) 207-244.

Lance, C. E.,\&Vandenberg, R. J. (2001). Confirmatory factor analysis. In F. Drasgow\&N. Schmitt (Eds.), Measuring and analyzing behavior in organizations: Advances in measurement and data analysis (pp. 221256). San Francisco: Jossey-Bass.

Leana, C., Appelbaum, E. ve Shevchuk, I. (2009). Work Process and Quality of Care in Early Childhood Education: The Role of Job Crafting. Academy of Management Journal, 52(6), 1169-1192.

Lichtenthaler, P. W ve Fischbach, A. (2016). Promotion-and Prevention-Focused Job Crafting: A Theoretical Extension and Meta-Analytical Test (5-9 Ağustos 2016). 76. Annual Meeting of the Academy of Management Proceedings içinde, California, ABD.

Liu Y. (2003). Developing a scale to measure the interactivity of websites, Journal of Advertising Research, 43(2), 207-217.

Loi, R., Ngo, H. Y. ve Foley, S. (2004). The Effect of Professional Identification on Job Attitudes: A Study of Lawyers in Hong Kong, Organizational Analysis, 12, 109-128.

Luthans, F., Youssef, C.M. ve Avolio, B.J. (2007). Psychological Capital: Developing the Human Competitive Edge, Oxford University Press, New York.

Mael, F.A. ve Ashforth, B.E. (1992). Alumni and Their Alma Mater: A Partial Test Of The Reformulated Model Of Organizational Identification. Journal of Organizational Behavior, 13, 103-123.

Maritz, L. (2011). Experiencing Psychological Ownership: A Qualitative Study. Yüksek Lisans Tezi, Paretoria Üniversitesi, Güney Afrika.

Marsh, H.W. ve Hocevar, D. (1985). Application of confirmatory factor analysis to the study of self-concept: First- and higher-order factor models and their invariance across groups. Psychological Bulletin, 97, 562-582.

Mayhew, M.G., Ashkanasy, N.M., Bramble, T., Gardner, J. (2007), “A Study of The Antecedents and Consequences of Psychological Ownership in Organizational Settings", The Journal of social psychology, 147(5), 477-500.

Miscenko, D. Ve Day, D.V. (2016). Identity and identification at work. Organizational

Psychology Review, 6, 215-247.

Niessen, C., Weseler, D. ve Kostova, P. (2016). When and Why Do Individuals Craft Their Jobs? The Role of Individual Motivation and Work Characteristics For Job Crafting. Human Relations. 69.6, 1287-1313.

Olckers, C., Plessis, D. (2012). The Role of Psychological Ownership in Retaning Talent: A Systematic Literature Review. Journal of Human Resource, 10 (2), 1-18. 
M. Begenirbaş - Y. Gökmen - R. Can Yalçın 13/2 (2021) 1127-1143

Qing Miao, Nathan Eva, Alexander Newman \& Gary Schwarz (2019) Public service motivation and performance: The role of organizational identification, Public Money \& Management, 39:2, 77-85.

Petrou, P., Demerouti, E. ve Schaufeli, W. B. (2015). Job Crafting in Changing Organizations: Antecedents and Implications for Exhaustion and Performance. Journal of Occupational Health Psychology, 20(4), 470480 .

Pierce, J.L, Rubenfield, S.A, Morgan, S. (1991) Employee ownership: A Conceptual Model of Process and Effects. Academy of Management Review, 16 (1), 121-144.

Pierce, J.L.,Kostova, T., Dirks, K.T. (2001), “Toward a Theory of Psychological Ownership in Organizations”, Academy of Management Review, 26(2), 298-310.

Pierce, J. L., Kostova, T., \& Dirks, K. T. (2003). The state of psychological ownership: Integrating and extending a century of research. Review of General Psychology, 7, 84-107.

Pierce, J L., Jussila, I., Cummings, A. (2009), "Psychological Ownership within The Job Design Context: Revision of The Job Characteristics Model", Journal of Organizational Behavior, 30(4), 477-496.

Pierce, J.L. ve Jussila, I. (2011). Psychological Ownership and the Organizational Context: Theory, Research Evidence, and Application. Edward Elgar, 15-56.

Pierce, J.L. ve Peck, J. (2018), “The History of Psychological Ownership and its Emergence in Consumer Psychology," in Psychological Ownership and Consumer Behavior, Edited by Joann Peck and Suzanne B. Shu, Springer.

Ravichandran, T, and Arun Rai. 1999. "Total Quality Management in Information Systems Development: Key Constructs and Relationships." Journal of Management Information Systems 16(3):119-155.

Riketta, M. (2005). Organizational identification: A meta-analysis. Journal of Vocational Behavior, 66, 358-384.

Schermelleh E. K., Moosbrugger, H. ve Muller, H. (2003). Evaluating the fit of structural equation models: Tests of significance and descriptive goodness-of-fit measures. Methods of Psychological Research Online, $8(2), 23-74$.

Schermelleh-Engel, K., Moosbrugger, H., \& Müller, H. (2003).Evaluating the Fit of Structural Equation Models: Tests of Significance and Descriptive Goodness-of-Fit Measures. Methods of Psychological Research Online, 8(2), 23-74.

Schober, P., Boer, C., \& Schwarte, L. A. (2018). Correlation coefficients: appropriate use and interpretation. Anesthesia \& Analgesia, 126(5), 1763-1768.

Shenavar, F. (2017). Assessment the mediating role of person-job fit and psychological ownership in the relationship between job crafting and job satisfaction. Journal of Psychology, 20(4), 376-392.

Skorikov, V.B. ve Vondracek, F.W. (2011). Occupational Identity. In: Schwartz S., Luyckx K., Vignoles V. (eds) Handbook of Identity Theory and Research. Springer, New York

Slemp, G.R. \& Vella-Brodrick, D.A. (2013). "The Job Crafting Questionnaire: A New Scale To Measure The Extent To Which Employees Engage in Job Crafting". International Journal of Wellbeing, 3(2): 126-146.

Snape, E. ve Redman, T. (2003). An evaluation of a three-component model of occupational commitment: Dimensionality and consequences among United Kingdom human resource management specialists. Journal of Applied Psychology, 88, 152-159.

Staw, B.M., Boettger, R.D. (1990). Task revision: A neglected form of work performance. Academy of Management Journal, 33, 534-559.

Steiger, J.H. (1990). Structural model evaluation and modification: An interval estimation approach. Multivariate Behavioural Research, 25, 173-180.

Streiner, D.L., Norman, G.R., 2003. Health Measurement Scales: A Practical Guide to their Development and Use. Oxford University Press, Oxford.

Tajfel, H. ve Turner J.C. 1985. The Social Identity Theory of Intergroup Behavior, in S.Worchel and W.G. Austin (ed.), Psychology of Intergroup Relations. Chicago: Nelson-Hail, 7-24. 
M. Begenirbaş - Y. Gökmen - R. Can Yalçın 13/2 (2021) 1127-1143

Tims, M., Bakker, A.B. \& Derks, D. (2012) “Development and Validation of The Job Crafting Scale”. Journal of Vocational Behavior, 80, 173-186.

Ullman, J.B. (2001). Structural equation modeling, Içinde: B. G. Tabachnick ve L. S. Fidel (Ed.), Using multivariate statistics, (4th ed; s.:653- 771), MA: Allyn\&Bacon.

Vandewalle, D.Van Dyne, L. ve Kostova, T. (1995). Psychological Ownership: An Empirical Examination of its Consequences, Group \& Organization Management, 20(2), 210-226.

Vandenberg, R. J. (2006). Introduction: statistical and methodological myths and urban legends: where, pray tell, did they get this idea? Organizational Research Methods, 9(2): 194-201.

Van Dick, R. Wagner U.Stellmacher J. (2005). Category Salience and Organizational Identification, Journal of Occupational and Organizational Psychology, 78, 273-285.

Van Dick, R., Wagner, U., Stellmacher, J., Christ, O. (2004). The Utility of a Broader Conceptualization of Organizational Identification: Which Aspects Really Matter? Journal of Occupational and Organizational Psychology, 77, 171-191.

Van Dyne, L. ve Pierce, J.L. (2004). Psychological Ownership And Feelings Of Possession: Three Field Studies Predicting Employee Attitudes And Organizational Citizenship Behavior, Journal of Organizational Behavior, 25(4), 439-459.

Wang, H. J., Demerouti, E. ve Le Blanc, P. (2017a). Transformational Leadership, Adaptability, And Job Crafting: The Moderating Role Of Organizational Identification, Journal of Vocational Behavior, 100, 185-195.

Wang, H., Demerouti, E., \& Le Blanc, P. M. (2017b). A job crafting perspective on empowering leadership and job performance. Paper Presented at the 77th Annual Meeting of the Academy of Management, Atlanta, GA.

Wang, H.J., Demerouti, E., Blanc, P.L. and Lu, C.Q. (2018), “Crafting a job in 'tough times': when being proactive is positively related to work attachment", Journal of Occupational and Organizational Psychology, Vol. 91 No. 3, pp. 569-590.

Wagner, S.H., Parker, C.P. ve Christianson, N.D. (2003). Employees that Think and Act Like Owners: Effects of Ownership Beliefs and Behaviors on Organizational Effectiveness, Personal Psychology, 56: 847-871.

Witt, L. A. (1993). Reactions to Work Assignment As Predictors Of Organizational Commitment: The Moderating Effect Of Occupational İdentification. Journal of Business Research, 26, 17-30.

Wrzesniewski, A., \& Dutton, J. E. (2001). Crafting A Job: Revisioning Employees As Active Crafters Of Their Work. Academy of Management Review, 26, 179-201.

Yavuz, M. (2018). İş Zanaatkârlığı İle Bireysel Performans Çıktıları Arasındaki İlişkide Çalışanların Dışsal Prestij ve Kurum Destek Algılarının Rolü. (Yayınlanmış Doktora Tezi). Marmara Üniversitesi, 44-93. 